\title{
A new aromatic ester from the mangrove plant Lumnitzera racemosa willd ${ }^{+}$
}

\author{
Ammanamanchi S.R.Anjaneyulu*, Yellajosyula L.N.Murthy, \\ Vadali Lakshmana Rao, Karanam Sreedhar \\ School of Chemistry, Andhra University, Visakhapatnam 530 003, India \\ E-mail: anjaneyuluasr@yahoo.com
}

\section{Dedicated to Prof. Sukh Dev on the occasion of his eightieth birthday \\ (received 07 Oct 02; accepted 13 Jan 03; published on the web 16 Jan 03)}

\begin{abstract}
Chemical examination of the Indian-mangrove plant Lumnitzera racemosa Willd has resulted in the isolation of a new aromatic ester besides the known triterpenoids, friedelin, betulin and betulinic acid. The structure of the new compound was established as 3-(4-hydroxyphenyl)propyl-3 ${ }^{1}$-(3,4- dihydroxyphenyl)-propionate by a study of its spectral data.
\end{abstract}

Keywords: Mangrove plant, Lumnitzera racemosa, a new aromatic ester

\section{Introduction}

Lumnitzera racemosa Willd (Fam: Combretaceae) is a handsome shrub or a small tree found on the coast of India and on the Andaman and Nicobar Islands. The wood of L. racemosa is used as a fuel for its calorific value and the leaves of the plant are eaten in South Pacific Island during periods of scarcity. The reddish brown bark contains 15-19\% tannin while the leaves and wood contain smaller quantities. A fluid obtained from incisions made in the stem was reported to be employed as an external application for the treatment of herpes and itches ${ }^{1}$. Antihypertensive activity has been recently reported for the aqueous acetone extract of the plant ${ }^{2}$. Chemical examination of this plant occurring in various parts of the world was reported to give a large number of compounds, long chain rubber like polyisoprenoid alcohols in leaves ${ }^{3}$, flavonoids and long chain fatty acids ${ }^{4}$ and low molecular weight carbohydrates ${ }^{5}$. Chemical examination of the Indian species was reported to give friedelin, $\beta$-amyrin, taraxerol, betulin, $\beta$-sitosterol and triacontanol ${ }^{6}$. The presence of trace elements was also reported ${ }^{7}$. In our continuing interest on the chemical constituents of Indian mangrove plants ${ }^{8-17}$ we have examined this species collected from the Bhiravapalem Island in the Godavary estuary and the results are reported herein. 


\section{Results and Discussion}

The air dried and powdered stem of $L$. racemosa was exhaustively extracted with $\mathrm{CH}_{2} \mathrm{Cl}_{2}$ : $\mathrm{MeOH}$ (1:1). Removal of the solvent from the combined $\mathrm{CH}_{2} \mathrm{Cl}_{2}: \mathrm{MeOH}$ extracts gave a residue which was extracted with EtOAc. Removal of the ethyl acetate under reduced pressure gave a residue which on repeated chromatographic separations over silica gel columns furnished a new aromatic ester $\mathbf{1}$, in addtion to the known triterpenoids, friedelin, betulin and betulinic acid.

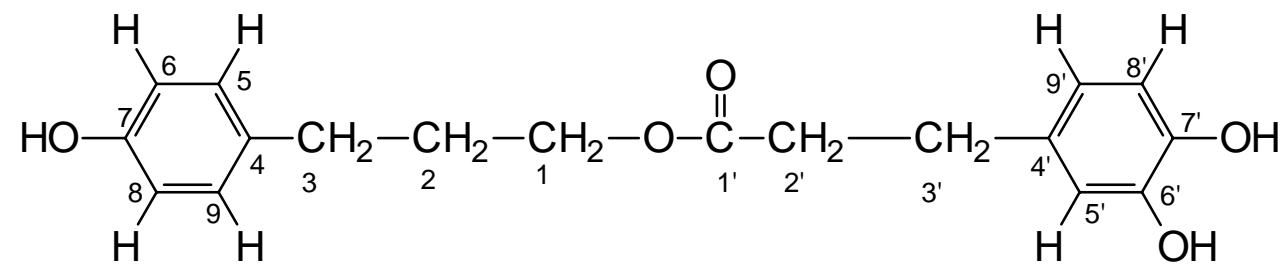

\section{Figure 1}

The new aromatic ester $\mathbf{1}, \mathrm{mp} \cdot 185^{\circ} \mathrm{C}$ was analysed for $\mathrm{C}_{18} \mathrm{H}_{20} \mathrm{O}_{5}$ and its identity supported by the mass ion at $\mathrm{m} / \mathrm{z} 299\left[\mathrm{M}+\mathrm{H}-\mathrm{H}_{2} \mathrm{O}\right]^{+}$in its positive $\mathrm{FAB}$ mass spectrum. The IR band at $1708 \mathrm{~cm}^{-1}$ indicated the presence of an ester carbonyl and a strong peak at $3443 \mathrm{~cm}^{-1}$ attributed to the phenolic hydroxyls. The molecular formula suggested nine double bond equivalents suggesting the presence of two aromatic rings besides the ester functionality. The ${ }^{1} \mathrm{H}$ NMR spectrum of 1 exhibited a splitting pattern consistent with a p-hydroxyphenyl substituted $\mathrm{A}_{2} \mathrm{~B}_{2}$ system, $\delta 6.99\left(2 \mathrm{H}, \mathrm{d}, \mathrm{J}=7.1 \mathrm{H}_{\mathrm{z}}\right)$ and $\delta 7.29\left(2 \mathrm{H}, \mathrm{d}, \mathrm{J}=7.1 \mathrm{H}_{\mathrm{z}}\right)$ and a 3,4-dihydroxy-substituted phenyl ABC system with the signals for the three protons appearing at $\delta 6.82\left(1 \mathrm{H}, \mathrm{d}, \mathrm{J}=7 \mathrm{H}_{\mathrm{z}}\right), \delta$ $6.59\left(1 \mathrm{H}, \mathrm{d} / \mathrm{d}, \mathrm{J}=7 \mathrm{H}_{\mathrm{z}}, 1 \mathrm{H}_{\mathrm{z}}\right)$ and $\delta 5.29\left(1 \mathrm{H}, \mathrm{d}, \mathrm{J}=1 \mathrm{H}_{\mathrm{z}}\right)$. The spectrum also indicated two benzylic methylenes and three aliphatic methylenes (Table 1). The chemical shifts and the multiplicities of the methylene protons clearly suggested 3- phenyl propyloxy system and 3phenylpropionic acid system linked as an ester. The ${ }^{13} \mathrm{C}$ NMR spectrum of $\mathbf{1}$ showed only sixteen signals for the eighteen present suggesting two sets of identical carbons accounting for the p-hydroxyphenyl substituted ring system. The chemical shifts of the respective carbon atoms were assigned on the basis of comparative data and HMQC data. The ester carbonyl appeared at 173.9 (s) and the oxymethylene carbon at $63.8(\mathrm{t})$. The ${ }^{1} \mathrm{H}-{ }^{1} \mathrm{H}$ COSY data (Table 1) supported the expected connectivities. Similarly, the HMBC data, for example, the connectivities between the oxymethylene protons at $\delta 4.05$ and $\mathrm{C}-2$ and C-3 carbons and the connectivities between the methylene protons at $\delta 2.25$ adjacent to the carbonyl, with carbonyl carbon $\mathrm{C}-1^{1}$ and benzylic methylene carbon C- $3^{1}$ and other connectivities (Table 1) were in full agreement with the structure of the new aromatic ester as 3-(4-hydroxyphenyl )-propyl-3 $3^{1}$-(3,4 dihydroxyphenyl )propionate (1). Final proof for the structure of $\mathbf{1}$ was provided by its hydrolysis with alcoholic $\mathrm{KOH}$ and obtaining 3-(4-hydroxyphenyl)-1-propanol ${ }^{21}$ and 3,4-dihydroxydihydrocinnamic acid ${ }^{22}$ identified with the literature compounds ( m.p \& ${ }^{1} \mathrm{HNMR}$ ). 
Table 1. ${ }^{1} \mathrm{H},{ }^{13} \mathrm{C}$ NMR, ${ }^{1} \mathrm{H}-{ }^{1} \mathrm{H}$ COSY and HMBC data of compound 1

\begin{tabular}{|c|c|c|c|c|}
\hline Carbon no. & $\begin{array}{l}{ }^{1} \mathrm{H}(\delta) \\
\left(300 \mathrm{MH}_{\mathrm{z}}\right)\end{array}$ & $\begin{array}{l}{ }^{13} \mathrm{C}(\delta) \\
\left(75 \mathrm{MH}_{\mathrm{z}}\right)\end{array}$ & COSY & HMBC \\
\hline $\mathrm{C}-1$ & $4.05(2 \mathrm{H}, \mathrm{t}, 4.5)$ & 63.8 & $\mathrm{H}-2$ & C-3, C-2, C- $1^{1}$ \\
\hline $\mathrm{C}-2$ & $2.09(2 \mathrm{H}, \mathrm{t} / \mathrm{t}, 4.5,6.6)$ & 28.6 & & C-3, C-1, C-4 \\
\hline C-3 & $2.80(2 \mathrm{H}, \mathrm{t}, 6.6)$ & 33.9 & $\mathrm{H}-2$ & C-5, C-9, C-4, C-1, C-2 \\
\hline C-4 & & 137.8 & & \\
\hline C-5 & $7.29(1 \mathrm{H}, \mathrm{d}, 7.5)$ & 132.1 & $\mathrm{H}-6$ & C-3, C-6, C-8, C-7, C-9 \\
\hline C-6 & $6.99(1 \mathrm{H}, \mathrm{d}, 7.5)$ & 123.5 & & C-8, C-5, C-9, C-4, C-7 \\
\hline C-7 & & 154.2 & & \\
\hline C-8 & $6.99(1 \mathrm{H}, \mathrm{d}, 7.5)$ & 123.5 & & \\
\hline C-9 & $7.29(1 \mathrm{H}, \mathrm{d}, 7.5)$ & 132.1 & & \\
\hline $\mathrm{C}-1^{1}$ & & 173.9 & & \\
\hline $\mathrm{C}-2^{1}$ & $2.25(2 \mathrm{H}, \mathrm{t}, 5.5)$ & 32.7 & & $\mathrm{C}-3^{1}, \mathrm{C}-4^{1}, \mathrm{C}-1^{1}$ \\
\hline$C-3^{1}$ & $2.82(2 \mathrm{H}, \mathrm{t}, 5.5)$ & 26.9 & $\mathrm{H}-2^{1}$ & $\mathrm{C}-2^{1}, \mathrm{C}-1^{1}, \mathrm{C}-5^{1}, \mathrm{C}-9^{1}, \mathrm{C}-4^{1}$ \\
\hline$C-4^{1}$ & & 132.6 & & \\
\hline$C-5^{1}$ & $5.29(1 \mathrm{H}, \mathrm{d}, 1.2)$ & 112.6 & & $\mathrm{C}-3^{1}, \mathrm{C}-9^{1}, \mathrm{C}-4^{1}, \mathrm{C}-7^{1}, \mathrm{C}-6^{1}$ \\
\hline $\mathrm{C}-6^{1}$ & & 149.1 & & \\
\hline $\mathrm{C}-7^{1}$ & $5.64(\mathrm{OH})$ & 142.5 & & $\mathrm{C}-8^{1}, \mathrm{C}-7^{1}, \mathrm{C}-6^{1}$ \\
\hline$C-8^{1}$ & $6.82(1 \mathrm{H}, \mathrm{d}, 8.0)$ & 115.0 & $\mathrm{H}-9^{1}$ & $\mathrm{C}-9^{1}, \mathrm{C}-4^{1}, \mathrm{C}-7^{1}, \mathrm{C}-6^{1}$ \\
\hline$C-9^{1}$ & $6.59(1 \mathrm{H}, \mathrm{dd}, 8.0,1.2)$ & 121.4 & & $\mathrm{C}-3^{1}, \mathrm{C}-5^{1}, \mathrm{C}-7^{1}$ \\
\hline
\end{tabular}

Chemical shifts in $\delta$ from TMS taken in $\mathrm{CDCl}_{3}$ with multiplicity and $\mathrm{J}$ values given in the brackets.

\section{Experimental Section}

General experimental procedures. Melting points were determined on a VEB-analytic Dreader HMK hot plate and are uncorrected. IR spectra were recorded on a Perkin-Elmer-841 IR spectrometer in $\mathrm{CHCl}_{3}$ solution. ${ }^{1} \mathrm{H}$ NMR spectra were measured on a Bruker Advance DRX 300 and Jeol JNM EX-90 spectrometers. ${ }^{13} \mathrm{C}$ NMR spectra were measured on a Bruker Advance DRX 300 spectrometers at $75 \mathrm{MH}_{\mathrm{z}}$ and Jeol JNM EX-90 spectrometer at $22.5 \mathrm{MH}_{\mathrm{z}}$ using $\mathrm{CDCl}_{3}$ as a solvent and tetramethylsilane as an internal reference. Elemental analyses were determined on a Carlo Ebra 1108 instrument. Mass spectra were obtained on a Jeol JMS-300 spectrometer.

Plant material. The stems of Lumnitzera racemosa were collected at the Bhiravapalem Island in the Godavari estuary ( $16^{0} 58^{1} \mathrm{~N}$ Latitude and $82^{0} 15^{1} \mathrm{E}$ Longitude) in March 1998. The plant material was identified by Prof. B.KondalaRao Dept of Marine Living Resourses, Andhra University and the voucher specimens of the material have been kept in the museums of Organic chemistry, School of Chemistry, Andhra university and NIO Goa as AU1-166. 
Extraction and isolation. The air-dried and powdered stem of Lumnitzera racemosa (4Kg) was exhaustively extracted with $\mathrm{CH}_{2} \mathrm{Cl}_{2}$ : $\mathrm{MeOH}$ (1:1) (8X8L). Removal of the solvent from the combined $\mathrm{CH}_{2} \mathrm{Cl}_{2}$ : $\mathrm{MeOH}$ extracts gave a residue $(20 \mathrm{~g})$ which was extracted with EtOAc (3 X $500 \mathrm{~mL}$ ). Removal of the solvent under reduced pressure gave a residue (15 g) which was subjected to column chromatography over a column of silica gel (Acme brand , 100-200 mesh, 400 g) using solvents of increasing polarity from n-hexane through EtOAc. In all, 260 fractions $(750 \mathrm{~mL})$ were collected. The fractions showing similar spots were combined and the residues from therein were subjected to chromatography over silica gel or silver nitrate (20\%) impregnated silica gel columns to yield four pure compounds as given below.

Fraction I. The residue (800 mg) from the column fractions 95-125 (n-hexane: EtOAc,8.75:1.25) was rechromatographed over a small column of silica gel using n-hexane and ethyl acetate mixtures as eluant to afford pure compound 1, an aromatic compound (90 mg), crystallised from methanol as colourless needles. m.p $185^{0} \mathrm{C}$, IR (Nujol) : $1708 \mathrm{~cm}^{-1}(\mathrm{C}=\mathrm{O})$, $3443 \mathrm{~cm}^{-1}(\mathrm{OH})$, EIMS: m/z $299\left[\mathrm{M}+\mathrm{H}-\mathrm{H}_{2} \mathrm{O}\right]^{+}$, Anal: Calcd for $\mathrm{C}_{18} \mathrm{H}_{20} \mathrm{O}_{5}, \mathrm{C}, 68.35$; H, 6.32 Found: C, 68.31 ; H, 6.28. For ${ }^{1} \mathrm{H}$ and ${ }^{13} \mathrm{CNMR},{ }^{1} \mathrm{H}-{ }^{1} \mathrm{H}$ COSY, and HMBC data see Table 1

Fraction II. The residue (2 g) from the column fractions 35-60 ( n-hexane : EtOAc, 9.5:5 ) was chromatographed through a small column of silica gel using n-hexane and ethyl acetate as eluants. The initial eluant fractions afforded compound 2, friedelin (200 mg) (crystalised from methanol) mp $268^{0}[\alpha]_{\mathrm{D}}{ }^{25}(-) 27.6^{0}\left(\mathrm{c}, 1.2\right.$ in $\left.\mathrm{CHCl}_{3}\right)$. IR (Nujol) : $1695 \mathrm{~cm}^{-1}(\mathrm{C}=\mathrm{O})$, EIMS: $\mathrm{m} / \mathrm{z} 426[\mathrm{M}]^{+},{ }^{1} \mathrm{H}$ NMR $\left(90 \mathrm{MH}_{\mathrm{z}} \mathrm{CDCl}_{3}\right)$ and ${ }^{13} \mathrm{C}\left(22.5 \mathrm{MH}_{\mathrm{z}} \mathrm{CDCl}_{3}\right)$. Comparison of the physical and spectral data of 2 with the literature value $e^{6,18,20}$ of friedelin confirmed the characterization.

Fraction III. The residue (1.2 g) from the column fractions 60-95 (n-hexane:EtOAc,9.0:1.0) was rechromatographed through a small column of silica gel using n-hexane and ethyl acetate as eluants. The initial eluant fractions afforded compound 3, betulin (120 mg) crystalised from MeOH- $\mathrm{CHCl}_{3}$, m.p $252^{0} \mathrm{C}$, $[\alpha]_{\mathrm{D}}{ }^{25}(+) 20.0^{0}$ ( c,1.2 pyridine) IR (Nujol) : $3560 \mathrm{~cm}^{-1}(\mathrm{OH})$, EIMS: $\mathrm{m} / \mathrm{z} 442[\mathrm{M}]^{+},{ }^{1} \mathrm{H}$ NMR $\left(90 \mathrm{MH}_{\mathrm{z}} \mathrm{CDCl}_{3}\right)$ and ${ }^{13} \mathrm{C}\left(22.5 \mathrm{MH}_{\mathrm{z}} \mathrm{CDCl}_{3}\right)$. Comparison of the physical and spectral data of 3 with the literature values ${ }^{19,20}$ of betulin proved their identity.

Fraction IV. The residue (1.5 g) from the column fractions 125-180 (n- hexane:EtOAc,8:2) was green in colour and contained some impurity. The impurity was removed by repeated chromatography over small columns of silicagel using n-hexane:ethyl acetate mixtures as eluants . Repeated crystallisation of the residues from the column fractions from methanolchloroform , afforded pure compound 4, betulinic acid (900 mg) as colourless needles. $\mathrm{mp}$ $276^{0} \mathrm{C}[\alpha]_{\mathrm{D}}^{25}(+) 15.2^{0}$ ( c, 1.2, pyridine )IR (Nujol): $3485(\mathrm{OH}), 1720(\mathrm{C}=\mathrm{O}), 885\left(\mathrm{CH}_{2}\right) \mathrm{cm}^{-}$ ${ }^{1}$,EIMS: $\mathrm{m} / \mathrm{z} 456[\mathrm{M}]^{+},{ }^{1} \mathrm{H}$ NMR (90 $\mathrm{MH}_{\mathrm{z}} \mathrm{D}_{5}$ Pyridine) and ${ }^{13} \mathrm{C}$ ( $22.5 \mathrm{MH}_{\mathrm{z}} \mathrm{D}_{5}$ Pyridine ). Comparison of the physical and spectral data of $\mathbf{4}$ with the literature values ${ }^{19,20}$ of betulinic acid confirmed the characterization.

Alkaline hydrolysis of compound 1. To compound 1 (25 mg) dissolved in methanol (10 ml) was added methanolic $\mathrm{KOH}(10 \%, 5 \mathrm{ml})$ and the mixture refluxed on a steam bath for 1 hour. 
The mixture was diluted with water $(20 \mathrm{ml})$ and then extracted into ether. The ether solution after evaporation gave 3-(4-hydroxyphenyl)-1-propanol m.p $52^{\circ} \mathrm{C}$ identical with the literature compound ${ }^{21}$ (m.p, ${ }^{1} \mathrm{HNMR}$ taken on $90 \mathrm{MH}_{\mathrm{Z}}$ instrument in $\mathrm{CDCl}_{3}$ with $\mathrm{TMS}$ as internal standard). The alkaline aqueous solution from the reaction was acidified with dil $\mathrm{H}_{2} \mathrm{SO}_{4}$ and the acid liberated was extracted into ether. The ether solution after evaporation left a residue which on crystallization from chloroform-methanol gave 3,4-dihydroxydihydrocinnamic acid m.p 136$38^{0}$ identical with the literature compound ${ }^{22}$ ( m.p, ${ }^{1} \mathrm{HNMR}$ taken on $90 \mathrm{MH}_{\mathrm{Z}}$ instrument in $\mathrm{CDCl}_{3}$ with TMS as internal standard).

\section{Acknowledgements}

The authors are grateful to the Department of Ocean Development, New Delhi for funding and The Head, RSIC, Lucknow and the Co-ordinator, UGC-SAP Programme, School of Chemistry, Andhra University for providing the spectral data.

\section{References and Notes}

+ Part XI of the series “Chemical constituents of Indian Mangrove plants” for part X see ref.17.

1. The Wealth of India, Raw materials, Published by Publication and Information Directorate, CSIR , New Delhi, 1962, p182.

2. Lin,Ta-chen.; Hsu,Feng-lin.; Cheng,Juei-Tang. J.Nat.Prod. 1993, 56, 629.

3. Skoczylas,E.; Swiezewska,E.; Chojnacki,T.;Tanaka,Y. Plant Physiol.Bioche.1994, 32, 825.

4. Huangliang,Y.; Su,M.; Chen,P. Tianran Chanwu Yanjiu Yu Kaifa. 1994, 6, 6.

5. Popp, M. Z.Pflanzenphysiol. 1984, 113, 411.

6. Majumdar, S.G.;Patra, G. J.Indian Chem Soc. 1980, 57, 568.

7. Bhosale, L. J. Indian J.Mar.Sci. 1979, 8, 58.

8. Anjaneyulu, A S R.; Lakshmana Rao, V. Phytochemistry 2000, 55, 891.

9. Anjaneyulu, A S R.; Anjaneyulu, V.; Lakshmana Rao, V. Indian J. Chem. 2000, 39B, 803.

10. Anjaneyulu, A S R.; Lakshmana Rao, V. Nat. Prod. Lett. 2001, 15, 13.

11. Anjaneyulu, A S R.; Lakshmana Rao, V.; Sreedhar, K. J. Nat. Prod. 2002, 65, 382.

12. Anjaneyulu, A S R.; Anjaneyulu, V.; Lakshmana Rao, V. J. Asian Nat. Prod. 2002, 4, 53.

13. Anjaneyulu, A S R.; Lakshmana Rao, V. Phytochemistry. (In press).

14. Anjaneyulu, A S R.; Lakshmana Rao, V.; Lobkovsky, E.;Clardy, J. J. Nat. Prod. 2002, 65, 592.

15. Anjaneyulu, A S R.; Lakshmana Rao, V.; Sreedhar, K. Nat. Prod .Lett. (In press).

16. Anjaneyulu, A S R.; Lakshmana Rao, V. Phytochemistry (In press).

17. Anjaneyulu, A. S. R .;Lakshmana Rao, V. Phytochemistry (In press). 
18. Amarendra, P.; Swapan,K. C.; Heinz, R. J .Indian Chem . Soc. 1990, 67, 394.

19. Ghosh, A .G.; Mishra, S.; Dutta, A .K.; Chowdary, A. Phytochemistry. 1985, 24, 1725.

20. Mahato, S. B.; Kundu, A. P. Phytochemistry. 1994, 37, 1517.

21. The Aldrich Library of ${ }^{13} \mathrm{C}$ and ${ }^{1} \mathrm{H}$ FT-NMR Spectra, Edition-1, Vol. 2, p 409, CAS [1021017-0].

22. The Aldrich Library of ${ }^{13} \mathrm{C}$ and ${ }^{1} \mathrm{H}$ FT-NMR Spectra, Edition-1, Vol. 2, p 1038, CAS [107861-1]. 